\title{
Patent Trends of Carbonaceous Materials for Hydrogen Storage (II): Qualitative Analysis
}

\author{
Soo-Jin Park ${ }^{1, \uparrow}$, Byung-Joo Kim² and Young-Seak Lee ${ }^{3}$ \\ ${ }^{1}$ Dept. of Chemistry, Inha Univ., 253 Nam-gu, Incheon 402-751, Korea \\ ${ }^{2}$ Dept. of Green Chemistry \& Environmental Biotechnology, Univ. of Science and Technology, P.O. Box 107, Yuseong, Daejeon 305-600, Korea \\ ${ }^{3}$ Dept. of Fine Chemical Engineering and Chemistry, Chungnam National Univ., 220 Kung-dong, Yuseong, Daejeon 305-764, Korea \\ ‘e-mail:sjpark@inha.ac.kr \\ (Received July 24, 2007; Accepted November 1, 2007)
}

\section{1. 서 론}

1970년대 오일쇼크 이후 인류는 화석연료의 고갈에 대한 근 본적 대비책으로서 다양한 대체 에너지의 필요성을 절감하고 이에 대한 연구를 진행하여 왔다. 현재 부각되고 있는 대체 에 너지로는 태양열, 지열, 풍력, 해양에너지 등의 자연에너지와 수소에너지가 있으며, 이 중 수소는 가스상으로 저장 및 수송 이 용이하고 연소 시 생성물이 극소량의 질소산화물 외에 대 부분이 물이라는 점에서 공해의 문제가 발생하지 않는 장점이 있다. 더불어 타 대체에너지원에 비해 높은 에너지 저장 능력 (석유: $40,000 \mathrm{~J} / \mathrm{g}$, 석탄: $30,000 \mathrm{~J} / \mathrm{g}$, 수소: $120,000 \mathrm{~J} / \mathrm{g}$ )을 가지 며, 물로부터 얻어지기 때문에 무한에 가까운 생산이 가능할 뿐 아니라, 쉽게 다른 에너지로 전환이 가능하여 향후 화석연 료를 대체할 수 있는 가장 가능성이 높은 에너지로 인식되고 있다 [1-6].

이러한 수소에너지를 현실적으로 사용하기 위해서는 무엇보 다 고순도 수소의 제조, 안전한 수소 저장기술, 그리고 고효율 수소이용법 등이 선 개발되어야 할 과제이다. 이 가운데 수소의 저장은 연료전지의 상용화 가능성이 가시화된 현 시점에서, 수 소에너지의 안전한 사용을 위해 급히 해결되어야 할 부분이라 하겠다. 앞서 보고하였던 '탄소계 재료를 이용한 수소저장: (1) 정성적 분석'에서 언급하였던 것과 같이 현재까지 개발된 수 소저장방법으로는 액체수소저장법, 기체수소저장법, 수소저장 합금이 있으나, 액체 및 기체 저장법은 그 위험성이 높고, 합 금의 경우 비가역적 수소저장 메커니즘이라는 점에서 상용화 가 희박하다[3-5,7-10].

한편 탄소재료와 같은 다공성 재료를 이용한 물리흡착의 경 우 상온 및 상압에 가까운 조건에서 수소를 가역적으로 저장 하는 것이 가능하기 때문에 그 안전성 및 상업성이 높아 물리 흡착을 이용하여 고효율로 수소를 저장하고자 하는 연구가 다 수 이루어 지고 있는 상태이다. 현재까지 보고된 수소저장용 탄소계 재료는 활성탄소, 탄소나노튜브, 탄소나노섬유, 흑연 등 이며, 탄소자체만으로는 높은 수소저장값을 보이지 않는 것으 로 알려져 있다. 때문에 탄소표면에 다양한 표면처리나 수소
와 친화력이 높은 전이금속과 같은 물질을 도핑해 주는 연구 들도 꾸준히 보고되고 있으며, 금속이 도입되었을 경우 수소 저장량이 급격이 증대되는 것이 관찰되고 있다. 이러한 결과 는 도입된 금속에 의한 수소의 탄소내부로의 spill-over 현상에 서 기인된 것으로 판단되고 있다 [8,911].

하지만 아직까지 탄소계 재료를 이용한 수소저장기술은 메 커니즘의 규명이 명확하지 않으며, 표준샘플 또한 아직 정해 지지 않은 상태이며, 현재까지 보고된 값들은 상업화까지는 많 은 시간이 요구된다고 하겠다. 하지만 탄소계 재료를 이용하 여 상업화 수준의 수소저장치를 얻을 경우 기존의 다른 재료 와는 차별화된 반영구적이며, 안전한 저장기술을 확보할 수 있 기 때문에 해당 분야의 중요성은 아무리 강조해도 지나침이 없다고 할 수 있다.

따라서 해당분야의 원천기술 및 특허권을 선점하기 위해서 는 세계 각 연구진의 연구동향과 연구결과에 대한 철저한 분 석과 함께 향후 연구개발 방향을 수립하기 위한 특허 기초 데 이터가 절실히 요구된다.

본 총설은 앞서 보고하였던 '탄소계 재료를 이용한 수소저 장: (1) 정성적 분석'에 이은 (2) 정량적 분석에 대한 결과로서 수소저장용 탄소재료와 관련된 각 기술분야별 경쟁 연구진의 특허 출원동향을 분석하여 경쟁 연구진의 핵심 개발 분야 및 최근 개발 동향을 파악하고 나아가 선행 특허들의 동향 분석 을 통하여 효과적으로 향후 연구개발 방향을 수립함과 동시에 확보 가능한 지적재산권의 영역을 정하고 연구력을 집중하여, 향후 개발된 연구 및 기술에 대한 유효성을 판단하는 동시에 향후 분쟁 가능성에 대비함에 목표를 두었다.

\section{2. 특허 분석 방법}

본 총설에서는 기술적인 내용을 의미하는 정성분석을 중점 적으로 시행하였다. 정성적 분석을 위해 수소저장용 탄소재료 의 주요출원인 및 중요특허를 이용하여 그 사례를 몇 가지로 심층 분석하였으며 중요분야에 대한 기술의 흐름을 파악하고, 
중요특허를 선정하여 요약정리 및 핵심특허를 파악하였다. 수 소저장매체로서 탄소재료에 특징이 있는 특허를 중요특허로 선정하였으며, 전지, 저장장치 등의 적용분야에 특징이 있는 특허는 본 총설에서 제외하였다.

본 고에서는 수소저장용 탄소재료와 관련된 한·미·일·유럽 특허를 332건을 추출하여 특허맵을 작성하였으며, 2007년 4월 까지 탑재된 특허를 기초로 분석하였다. 정량분석 구간은 공 개시점을 고려하여 출원일 기준으로 2004년 12월까지의 특허 를 대상으로 하였다.

본 총설에서 지칭되는 수소저장용 탄소재료는 활성탄소 (Activated carbons, ACs 또는 activated carbon fibers, ACFs), 흑연 (Graphites 또는 다이아몬드), 탄소나노튜브 (Carbon nanotubes, CNTs), 탄소나노섬유 (Carbon nanofibers, CNFs 또 는 Graphite nanofibers, GNFs), 플러렌 (Fullerene), 범용 및 기 타의 7 개 분야로 분류하였으며, 상기 범용분야는 탄소재료로 서 특정 물질자체, 예로서 활성탄, 탄소나노튜브 등에 특징이 있는 것이 아니라, 복수개의 탄소재료 중 1종 또는 1종 이상 선택할 수 있는 기술 분류를 의미하고, 기타 기술 분야는 상 기 6개 분야에 속하지 않는 탄소재료, 새로운 형태의 탄소재 료 또는 특허 명세서상에 탄소재료의 구체적인 언급이 없는 기술 분류를 의미한다. 따라서, 상기 범용 기술 분류 때문에, 이후 특허 분석과정상에 어떤 특정 분야에 특허출원 또는 특 허등록이 수치적으로 나타나지 않았다고 하더라도, 그 분야에 특허활동이 전혀 이루어지지 않음을 의미하는 것이 아님을 명 시한다.

\section{3. 특허 정보 분석}

\section{1. 연구주체 특허동향}

한국 및 조사된 각 국가에서 특허출원 또는 등록한 연구주체 들의 연구활동을 관찰하기 위해 연구주체를 기업, 공공기관, 개 인 및 대학으로 분류하였다 [12-21].

Fig. 1 에서 관찰되는 것과 같이 한국특허에서 수소저장용 탄 소재료에 관한 특허의 주요 연구주체는 기업 (21건, $51 \%)$ 으로 공공기관 (7건, $17 \%)$ 및 개인 (7건, $17 \%)$ 보다 3 배 정도 높은 점유율을 보였으며, 대학의 경우 6 건 $15 \%$ 로 공공기관 및 개 인과 미미한 차이를 보이는 것으로 나타났다. 기업에서 수소 저장에 대한 높은 실적을 나타내는 것은 탄소재료를 이용한 수소저장분야가 산업적으로 큰 비중을 차지한 다는 의미로 받 아질 수 있다. 현재 미국과 일본의 경우 국가주도적으로 탄소 재료를 이용한 수소저장에 많은 금액의 연구비가 소요되고 있 다. 차세대 자동차인 연료전지-축전지 하이브리드형 동력원을 구동시키기 위해서는 무엇보다 연료전지의 실제 연료인 수소 를 안전하게 그리고 안정적으로 저장 및 운반할 수 있는 소재 의 개발이 필수적이고, 개발에 따른 산업적인 파급효과는 가 히 크다고 할 수 있다. 한편 각 연구주체들이 공통적으로 연
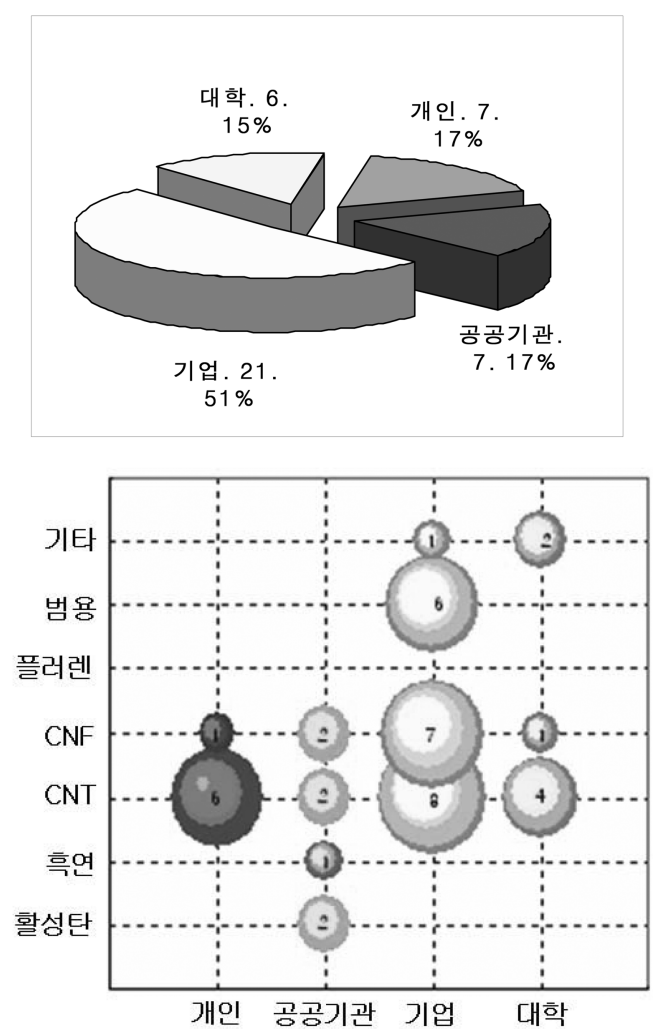

Fig. 1. 한국특허상 수소저장용 탄소재료 분야의 연구주체별-소 재별 특허동향 (출원년도 기준: 2004)

구한 소재는 탄소나노튜브와 탄소나노섬유로, 나노구조체를 이용한 수소저장에 대한 관심이 높은 것을 확인 할 있었다(탄 소나노튜브와 탄소나노섬유에 기업은 각각 8건과 7건, 개인은 6 건과 1 건, 대학은 4 건과 1 건, 공공기관은 2 건씩을 출원하였 음).

기업은 상기 주요 기술 이외의 범용 분야도 6 건을 출원하여 탄소나노튜브, 탄소나노섬유 및 범용에 집중적인 출원활동을 보였다. 공공기관만이 활성탄과 흑연분야에 각각 2 건과 1 건을 출원하였다.

미국특허에서 수소저장용 탄소재료에 관한 특허의 주요 연 구주체는 기업 (44건, $79 \%$ )으로 압도적인 점유율을 보였으며 (Fig. 2), 그 뒤를 대학 (8건 $14 \%)$, 공공기관 (3건 $8 \%$ ), 개인 $(1,2 \%)$ 이 따르고 있음이 관찰되었다. 미국의 경우 정부주도의 빠른 실용화를 위해 많은 기업들이 이 분야에 뛰어들고 있으 며, 이에 따라 실용적인 특허가 다수 보고되고 있다. 미국특허 에서의 특징은 국내의 경우 탄소나노섬유 및 탄소나노튜브와 같은 다소 벤처적인 소재에 집중된 반면 미국기업은 다른 기 술 분야보다 탄소나노섬유, 탄소나노튜브에 높은 등록 집중도 를 보이고 있기는 하지만, 흑연과 같은 전통적인 소재에도 높 은 집중도를 보이며, 전반적으로 모든 소재 분야에 고른 특허 활동을 보이고 있다는 점이다. 한편, 대학은 총 등록 건 8건 중 4 건을 탄소나노튜브에 등록하여 첨단 소재기술 분야에 높은 관 심을 보이는 것으로 나타났다. 개인은 활성탄에만 1 건이 등록 


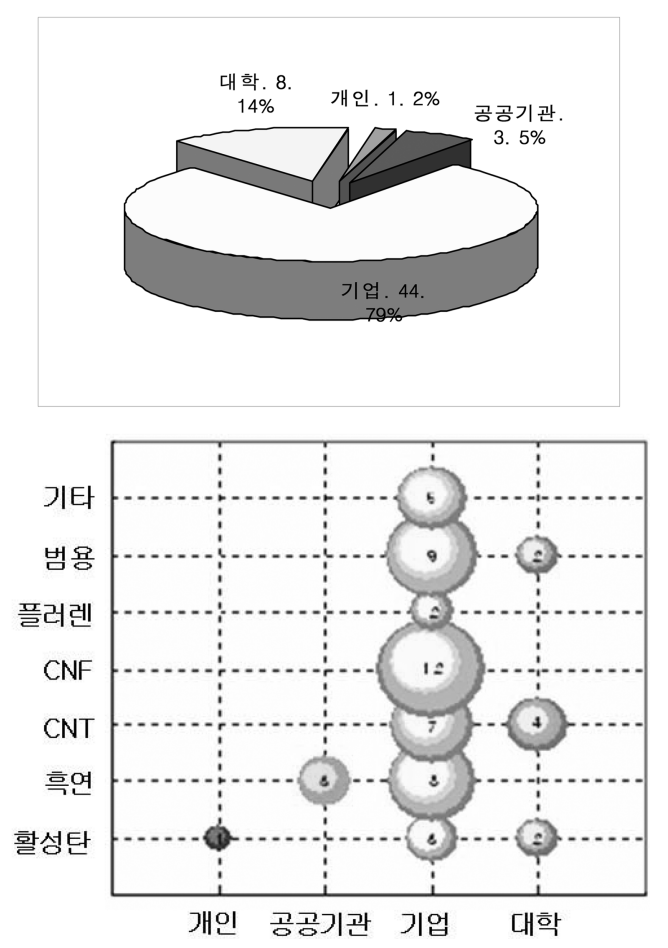

Fig. 2. 미국특허상 수소저장용 탄소재료 분야의 연구주체별-소 재별 특허동향 (등록년도 기준: 2006)

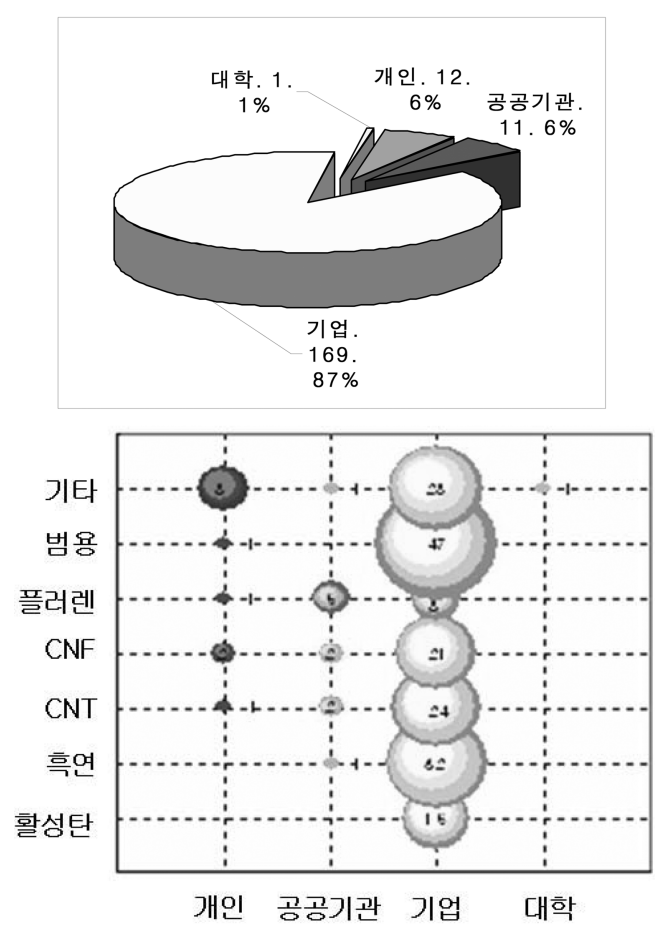

Fig. 3. 일본특허상 수소저장용 탄소재료 분야의 연구주체별-소 재별 특허동향 (출원년도 기준: 2004)

되었고, 공공기관은 흑연에 3건을 등록한 것으로 나타났다. 일본은 전통적으로 탄소재료에 대한 높은 기술우위를 가지

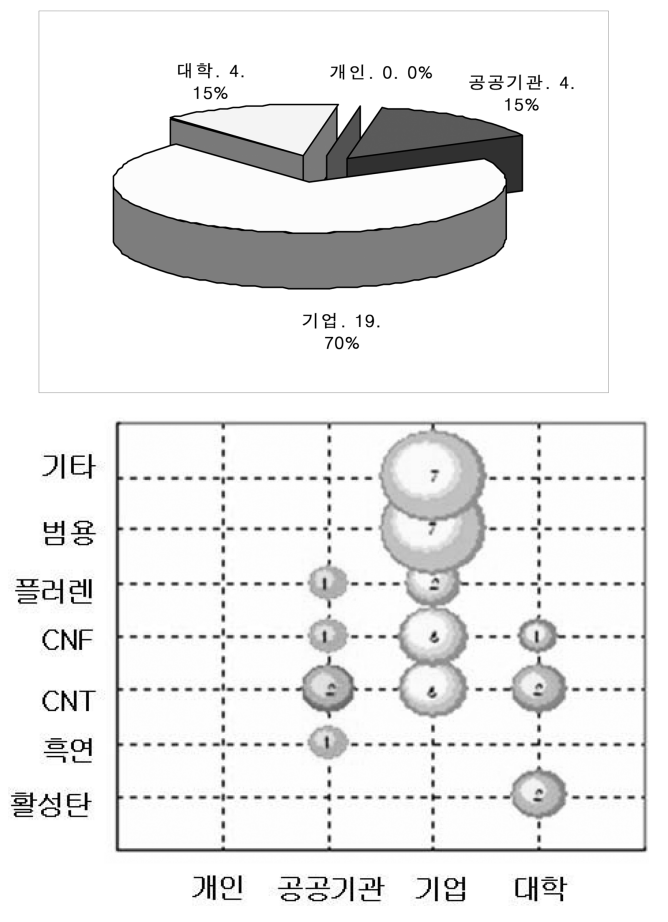

Fig. 4. 유럽특허상 수소저장용 탄소재료 분야의 연구주체별-소 재별 특허동향 (출원년도 기준: 2004)

고 있는 나라로서 특히 수소저장 및 다공성 탄소재료에 관한 연구활동은 독보적인 수준에 다다르고 있다. 일본특허 (Fig. 3) 에서 수소저장용 탄소재료에 관한 특허의 주요 연구주체는 기 업으로서 169 건 $87 \%$ 으로, 그 외 다른 연구주체에 비해 절대 적 우위를 선점하고 있고, 개인은 12 건 $6 \%$, 공공기관은 11 건 $6 \%$, 대학은 1 건 $1 \%$ 의 출원량을 나타냈다. 일본 기업은 미국 과 유사하게 전 기술 분야에 고른 특허활동을 보이며, 특히 범 용, 흑연, 탄소나노튜브, 기타 기술에 높은 특허출원량을 나타 냈다. 개인은 탄소나노튜브, 탄소나노섬유, 플러렌, 범용 및 기 타에 출원을 하였고, 공공기관은 흑연, 탄소나노튜브, 탄소나 노섬유, 플러렌 및 기타 기술에 출원을 하였으나, 기업의 출원 량에 비해 극히 낮은 수치임을 알 수 있다. 한편 활성탄을 이 용한 수소저장에 관해서는 기업만이 유일하게 출원하였는데, 이는 종래의 활성탄소를 생산하는 업체를 중심으로 수소저장 소재로의 전환가능성을 검토한 것으로 판단된다.

유럽특허 (Fig. 4)에서 수소저장용 탄소재료에 관한 특허의 주요 연구주체는 타국과 동일하게 기업으로서 19 건 $70 \%$ 로 가 장 높은 특허출원량을 보이고 있으며, 그 뒤를 이어 대학과 공 공기관이 4 건의 특허를 출원하여 $15 \%$ 의 점유율을 나타냈다. 기업은 활성탄과 흑연을 제외한 기술에 걸쳐 고른 특허활동을 보이고 있으며, 특히 범용과 기타 기술 분야에 각각 7건씩 전 체출원 19 건 중 총 14 건을 출원하여 높은 특허집중도를 보였 다. 공공기관은 흑연, 탄소나노섬유, 탄소나노튜브 및 플러렌 분야에 각각 1 건, 2 건, 1 건, 1 건을 대학은 활성탄, 탄소나노튜 브, 탄소나노섬유에 각각 2 건, 2 건, 1 건을 출원하였으나 기업 
Table 1. 한국특허상 수소저장용 탄소재료 소재별-주요 출원인 Top.5

\begin{tabular}{|c|c|c|c|c|c|c|c|c|}
\hline 순위 & 출원인 & 활성탄 & 출원인 & 흑연 & 출원인 & $\mathrm{CNT}$ & 출원인 & $\mathrm{CNF}$ \\
\hline 1 & 한국에너지기술연구원 & 1 & $\begin{array}{l}\text { 인스티튜트 포 } \\
\text { 에너지테크니크 }\end{array}$ & 1 & 이영희 & 4 & (주)넥센나노텍 & 4 \\
\hline 2 & 한국화학연구원 & 1 & & & 남기석 & 2 & $\begin{array}{c}\text { (주)에이엔티테크 } \\
\text { 놀러지 }\end{array}$ & 1 \\
\hline 3 & & & & & 한국과학기술원 & 2 & 강흥원 & 1 \\
\hline 4 & & & & & 한국화학연구원 & 2 & 모찌다이사오 & 1 \\
\hline 5 & & & & & 한윤봉 & 2 & 소니 & 1 \\
\hline 순위 & 출원인 & 플러렌 & 출원인 & 범용 & 출원인 & 기타 & & \\
\hline 1 & & & 소니 & 2 & 경원엔터프라이즈 (주) & 1 & & \\
\hline 2 & & & 로세터 홀딩스 & 1 & 삼성전자 & 1 & & \\
\hline 3 & & & 신에쓰가가꾸고교 & 1 & 서울대학교 & 1 & & \\
\hline 4 & & & $\begin{array}{c}\text { 에어프로덕츠앤드케 } \\
\text { 미칼스 }\end{array}$ & 1 & 유종성 & 1 & & \\
\hline 5 & & & $\begin{array}{c}\text { 크베르너 테크놀로지 } \\
\text { 앤드 리서치 }\end{array}$ & 1 & 한국과학기술원 & 1 & & \\
\hline
\end{tabular}

Table 2. 미국특허상 수소저장용 탄소재료 소재별-주요 등록권자 Top.5

\begin{tabular}{|c|c|c|c|c|c|c|c|c|}
\hline 순위 & 등록인 & 활성탄 & 등록인 & 흑연 & 등록인 & CNT & 등록인 & $\mathrm{CNF}$ \\
\hline 1 & Syracuse University & 2 & $\begin{array}{l}\text { Energy Conversion } \\
\text { Devices Inc }\end{array}$ & 3 & General Electric Co & 1 & Sony Corporation & 3 \\
\hline 2 & $\begin{array}{l}\text { Kabushiki Kaisha Toyota } \\
\text { Chuo Kenkyusho }\end{array}$ & 1 & $\begin{array}{l}\text { Texaco Ovonic Fuel } \\
\text { Cell, LLC }\end{array}$ & 2 & Have Blue, LLC & 1 & Canon Inc & 1 \\
\hline 3 & Klein Martin & 1 & Electrion, Inc & 1 & Honda Giken Kogyo KK & 1 & Enernext, LLC & 1 \\
\hline 4 & $\begin{array}{l}\text { Martin Marietta Energy } \\
\text { Systems, Inc }\end{array}$ & 1 & $\begin{array}{c}\text { Energy Development } \\
\text { Associates Inc }\end{array}$ & 1 & $\begin{array}{c}\text { Institute of Metal Research of } \\
\text { The Chinese Academy of } \\
\text { Sciences }\end{array}$ & 1 & $\begin{array}{c}\text { Ford Global } \\
\text { Technologies, Inc }\end{array}$ & 1 \\
\hline 5 & Nanomix, Inc & 1 & $\begin{array}{l}\text { General Motors } \\
\text { Corporation }\end{array}$ & 1 & Intel Corp & 1 & General Electric Co & 1 \\
\hline 순위 & 등록인 & 플러렌 & 등록인 & 범용 & 등록인 & 기타 & & \\
\hline 1 & $\begin{array}{c}\text { Materials and } \\
\text { Electrochemical Research } \\
\text { (MER) Corporation }\end{array}$ & 2 & Sony Corporation & 2 & $\begin{array}{l}\text { Air Products and Chemicals, } \\
\text { Inc }\end{array}$ & 1 & & \\
\hline 2 & & & $\begin{array}{l}\text { Air Products and } \\
\text { Chemicals, Inc }\end{array}$ & 1 & Infineon Technologies AG & 1 & & \\
\hline 3 & & & $\begin{array}{l}\text { Carnegie Mellon } \\
\text { University }\end{array}$ & 1 & $\begin{array}{l}\text { Nippon Mitsubishi Oil } \\
\text { Corporation }\end{array}$ & 1 & & \\
\hline 4 & & & $\begin{array}{l}\text { Catalytic Materials } \\
\text { Limited }\end{array}$ & 1 & $\begin{array}{c}\text { Ovonic Hydrogen Systems, } \\
\text { LLC }\end{array}$ & 1 & & \\
\hline 5 & & & Electrion, Inc & 1 & Proton Energy Systems, Inc & 1 & & \\
\hline
\end{tabular}

과 비교하여 특허활동이 상대적으로 미진한 것으로 나타냈다.

3.2. 소재별 주요출원인
각 소재에 따른 주요 출원인에 대해서 국가별로 알아보았으 며, 이를 통해 기업의 관심분야와 공공기관의 관심분야를 비 교 고찰하여 보았다 [12-21].

한국특허에서 수소저장용 탄소재료의 세부 소재별 주요출원 
Table 3. 일본특허상 수소저장용 탄소재료 소재별-주요 출원인 Top.5

\begin{tabular}{|c|c|c|c|c|c|c|c|c|}
\hline 순위 & 출원인 & 활성탄 & 출원인 & 흑연 & 출원인 & CNT & 출원인 & $\mathrm{CNF}$ \\
\hline 1 & $\begin{array}{l}\text { Toyota Central Res \& } \\
\text { Dev Lab Inc }\end{array}$ & 4 & Nissan Motor Co Ltd & 9 & Nissan Motor Co Ltd & 5 & Sony Corp & 4 \\
\hline 2 & Daikin Ind Ltd & 2 & Sanyo Electric Co Ltd & 5 & Sony Corp & 5 & Toshiba Corp & 3 \\
\hline 3 & Asahi Glass Co Ltd & 1 & $\begin{array}{l}\text { Hitachi Powdered Metals } \\
\text { Co Ltd }\end{array}$ & 4 & Air Water Inc & 2 & Canon Inc & 2 \\
\hline 4 & Japan Steel Works Ltd & 1 & Mitsubishi Heavy Ind Ltd & 3 & Honda Motor Co Ltd & 2 & $\begin{array}{l}\text { CMC Gijutsu } \\
\text { Kaihatsu K K }\end{array}$ & 2 \\
\hline 5 & $\begin{array}{l}\text { Mitsubishi Gas Chen Co } \\
\text { Inc }\end{array}$ & 1 & $\begin{array}{c}\text { Nippon Telegr \& Teleph } \\
\text { Corp }<\text { NTT }>\end{array}$ & 3 & Toyota Motor Corp & 2 & Denso Corp & 2 \\
\hline 순위 & 출원인 & 플러렌 & 출원인 & 범용 & 출원인 & 기타 & & \\
\hline 1 & $\begin{array}{c}\text { Japan Storage Battery Co } \\
\text { Ltd }\end{array}$ & 3 & Toyota Motor Corp & 11 & Asahi Kasei Chemicals Corp & 5 & & \\
\hline 2 & $\begin{array}{c}\text { Matsushita Electric Ind } \\
\text { Co Ltd }\end{array}$ & 3 & Sony Corp & 7 & Saito Hidetoshi & 5 & & \\
\hline 3 & $\begin{array}{l}\text { National Institute for } \\
\text { Materials Science }\end{array}$ & 3 & Fujii Hironobu & 3 & Sony Corp & 4 & & \\
\hline 4 & $\begin{array}{c}\text { Agency of Ind Science \& } \\
\text { Technol }\end{array}$ & 1 & Nikon Corp & 3 & Hitachi Chem Co Ltd & 3 & & \\
\hline 5 & Idemitsu Kosan Co Ltd & 1 & Nissan Motor Co Ltd & 3 & Nippon Mitsubishi Oil Corp & 3 & & \\
\hline
\end{tabular}

인 Top 5 를 살펴보면, 활성탄 분야에는 각각 출원건 1 건의 한 국에너지기술연구원과 한국화학연구원이, 흑연에는 출원건 1 건의 Institutt for Energiteknikk, 탄소나노튜브에는 개인으로서 출원건 4건의 성균관대 이영희 교수팀, 탄소나노섬유에는 출원 건 4건 (주)넥센나노텍이 주요 출원인인 것으로 분석되었다. 한 편, 범용 분야는 출원건 2 건의 소니가 주요 출원인인 것으로 나타났고, 기타 분야에는 경원엔터프라이즈(주), 삼성전자, 서 울대학교 등이 1 건씩의 출원을 보였다. 자세한 사항은 Table 1 에 나타내었다. 앞서 언급하였듯이, 수소저장관련 분야는 산 업화 시 높은 경제성이 기대되는 분야이기 때문에 기업의 관 심이 무엇보다 높은 것이 확인된다. 하지만 소재에 따른 연구 에서는 기업보다 대학 및 공공기관에서 첨단재료라 할 수 있 는 탄소나노튜브 및 탄소나노섬유 쪽으로 많이 집중되고 있는 것이 관찰되었다.

미국특허에서 수소저장용 탄소재료의 세부 소재별 주요등록 권자 Top 5 를 살펴보면, 활성탄 분야에는 등록건 2 건의 Syracuse University가, 흑연은 등록건 3건의 Energy Conversion Devices Inc, 등록건 2건의 Texaco Ovonic Fuel Cell, LLC 가, 탄소나노섬유는 등록건 3건의 Sony Corporation이 주요 등 록권자인 것으로 분석되었다. 탄소나노튜브 분야에는 General Electric Co, Have Blue, LLC, Honda Giken Kogyo KK 등의 등록권자가 1 건씩의 등록을 보였다. 플러렌 분야에는 등록건 2건의 Material and Electrochemical Research (MER) Corporation이, 범용 분야는 등록건 2건의 Sony Corporation이 주요 등록권자인 것으로 분석되었다. 기타 분야에는 Air
Products and Chemicals, Inc, Infineon Technologies AG 등의 등록권자가 1건씩 등록을 보였다 (Table 2).

미국의 경우는 한국의 경우보다 극심한 기업중심의 특허등 록이 이루어진 것을 확인 할 수 있다. 미국의 경우 정부의 강 력한 수소경제 추진에 따라 많은 연구비와 많은 연구진들이 참여하고 있으며, 특히 기업 중심으로 수소자동차의 실용화를 위해 매진하고 있다. 이를 반증 하듯이 전 탄소재료에 걸쳐 기 업들의 주도적인 특허 등록이 이루어지고 있음이 관찰되었다.

일본특허에서 수소저장용 탄소재료의 세부 소재별 주요출원 인 Top 5 를 살펴보면, 활성탄 분야에는 출원건 4 건의 Toyota Central Res \& Dev Lab Inc가 주요 출원인이고, Nissan Motor Ltd.는 출원건 9건과 출원건 5건으로 흑연과 탄소나노튜브의 주요 출원인이며, 또한 Sony Corp는 각각 출원건 5건과 4건 으로 탄소나노튜브와 탄소나노섬유 분야에 주요 출원인인 것 으로 분석되었다. Sony Corp는 탄소나노튜브와 탄소나노섬유 분야뿐만 아니라, 각각 출원건 7건과 4건으로 범용과 기타 분 야의 주요 출원인인 것으로 나타났다. 플러렌 분야에는 각각 출원건 3건의 Japan Storage Battery Co Ltd, Matauahita Electric Ind Co Ltd 및 National Institute for Materials Science 가, 범용은 출원건 11 건의 Toyota Motor Corp가, 기타 분야는 각각 출원건 5건의 Asahi Kasei Chemicals Corp, Saito Hidetoshi가 주요 출원인인 것으로 분석되었다 (Table 3).

일본 특허의 중요한 점은 Toyota 및 Nissan과 같은 메이져급 자동차 회사의 두드러진 특허활동이다. 일본은 실제적으로 하 이브리드카를 생산하고 있으며, 전국적인 보급을 위해 저가, 고 
Table 4. 유럽특허상 수소저장용 탄소재료 소재별-주요 출원인 Top.5

\begin{tabular}{|c|c|c|c|c|c|c|c|c|}
\hline 순위 & 출원인 & 활성탄 & 출원인 & 흑연 & 출원인 & CNT & 출원인 & $\mathrm{CNF}$ \\
\hline 1 & $\begin{array}{c}\text { Institute of Physics } \\
\text { Chinese Academy of } \\
\text { Sciences }\end{array}$ & 1 & $\begin{array}{c}\text { Institutt for } \\
\text { Energiteknikk }\end{array}$ & 1 & Sony Corporation & 2 & $\begin{array}{c}\text { C_R_F_ Societa } \\
\text { Consortile per Azioni }\end{array}$ & 1 \\
\hline 2 & Syracuse University & 1 & & & $\begin{array}{c}\text { C_R_F_ Societa } \\
\text { Consortile per Azioni }\end{array}$ & 1 & $\begin{array}{c}\text { Canon Kabushiki } \\
\text { Kaisha }\end{array}$ & 1 \\
\hline 3 & & & & & $\begin{array}{l}\text { Facultes Universitaires } \\
\text { Notre-Dame de la Paix }\end{array}$ & 1 & $\begin{array}{c}\text { Facultes } \\
\text { Universitaires Notre- } \\
\text { Dame de la Paix }\end{array}$ & 1 \\
\hline 4 & & & & & $\begin{array}{c}\text { General Electric } \\
\text { Company }\end{array}$ & 1 & $\begin{array}{c}\text { Osaka Gas Company } \\
\text { Limited }\end{array}$ & 1 \\
\hline 5 & & & & & $\begin{array}{c}\text { Institute of Metal } \\
\text { Research of the Chinese } \\
\text { Academy of Sciences }\end{array}$ & 1 & Sony Corporation & 1 \\
\hline 순위 & 출원인 & 플러렌 & 출원인 & 범용 & 출원인 & 기타 & & \\
\hline 1 & $\begin{array}{c}\text { Materials and } \\
\text { Electrochemical } \\
\text { Research Cooperation }\end{array}$ & 1 & $\begin{array}{l}\text { Air Products and } \\
\text { Chemicals, Inc }\end{array}$ & 1 & $\begin{array}{l}\text { Air Products and } \\
\text { Chemicals, Inc }\end{array}$ & 1 & & \\
\hline 2 & $\begin{array}{l}\text { National Institute for } \\
\text { Materials Science }\end{array}$ & 1 & Alcatel & 1 & $\begin{array}{c}\text { General Electric } \\
\text { Company }\end{array}$ & 1 & & \\
\hline 3 & Sony Corporation & 1 & $\begin{array}{c}\text { Catalytic Materials } \\
\text { Limited }\end{array}$ & 1 & Institutt for Energiteknikk & 1 & & \\
\hline 4 & & & Future Camp GMBH & 1 & $\begin{array}{l}\text { Japan Science and } \\
\text { Technology Agency }\end{array}$ & 1 & & \\
\hline 5 & & & $\begin{array}{l}\text { Kvaerner Technology } \\
\text { and Research Limited }\end{array}$ & 1 & $\begin{array}{l}\text { Nippon Mitsubishi Oil } \\
\text { Corporation }\end{array}$ & 1 & & \\
\hline
\end{tabular}

효율 수소자동차를 개발하고 있는 실정이다. 이러한 자국 내 수소경제의 급진적 발전은 메이져급 자동차 회사들의 꾸준한 연구활동을 통해 이루어진 것이라 할 수 있겠다. 한편, 전지회 사들의 특허출원도 상당한 것으로 확인되었다. 즉, 메이져급 자동차회사의 수소자동차 연구와 함께 수소전지 (연료전지) 개 발 또한 박차를 가하고 있음에 따라 관련 회사들의 특허활동 도 활발해진 것으로 관찰된다.

유럽특허에서 수소저장용 탄소재료의 세부 소재별 주요출원 인 Top5를 살펴보면, 활성탄 분야에는 출원건 1건의 Institute of Physics Chinese Academy of Sciences와 Syracuse University 가, 흑연에는 출원건 1건의 Institute for Energiteknikk가, 탄소 나노튜브에는 출원건 2건의 Sony Corporation이 주요 출원인 으로 나타났다. 탄소나노섬유에는 C.R.F. Societa Consortile per Azioni, Canon Kabushiki Kaisha, Facultes Universitaires Notre-Dame de la Paix, Sony Corporation 등이 출원을 보이고 있으며, C.R.F. Societa Consortile per Azioni, Facultes Universitaires Notre-Dame de la Paix는 탄소나노튜브에도 출원이 1 건씩 있음이 확인되었다. 플러렌 분야에는 출원건 1건의 Sony Corporation를 포함하여 Materials and Electrochemical Research Corporation, National Institute for Materials Science가
주요 출원인인 것으로 분석되었다. 범용과 기타에는 각각 출 원건 1건의 Air Products and Chemicals, Inc 등이 출원을 보 이고 있다 (Table 4). 유럽의 경우도 미국, 일본과 동일하게 기 업중심의 특허활동을 보이고 있는 반면, 주요 연구소재에서는 일부 차이를 나타내었다.

각국의 특허활동 및 주요 연구소재와 주요 출원진에 대한 확 인한 결과 다음과 같은 결론을 얻을 수 있었다. (1) 탄소재료 를 이용한 수소저장은 산업화 및 실용화가 가까움에 따라 기 업중심의 특허활동이 활발하다. (2) 한국의 경우 최근 들어 합 류하였기에 첨단소재인 탄소나노튜브 및 탄소나노섬유에 많은 비중이 있는 반면, 일본과 미국의 경우 흑연 및 범용 탄소재료 에도 많은 특허를 보유하고 있다. (3) Sony를 포함한 다국적 기업의 활동으로 주요 특허 보유사들의 활동이 두드러진다.

상기의 결론 중 (2) 결론에 대한 체계적인 관찰을 위해 특허 구간별 포트폴리오를 작성하였으며, 이를 통해 각국의 소재별 특허경향을 확인하여 보았다.

\section{3. 구간별 특허 포트폴리오}

본 포트폴리오는 특허출원건수와 출원인수간 상관관계를 통 해 기술의 발전, 성숙 및 퇴조단계를 한눈에 파악할 수 있는 


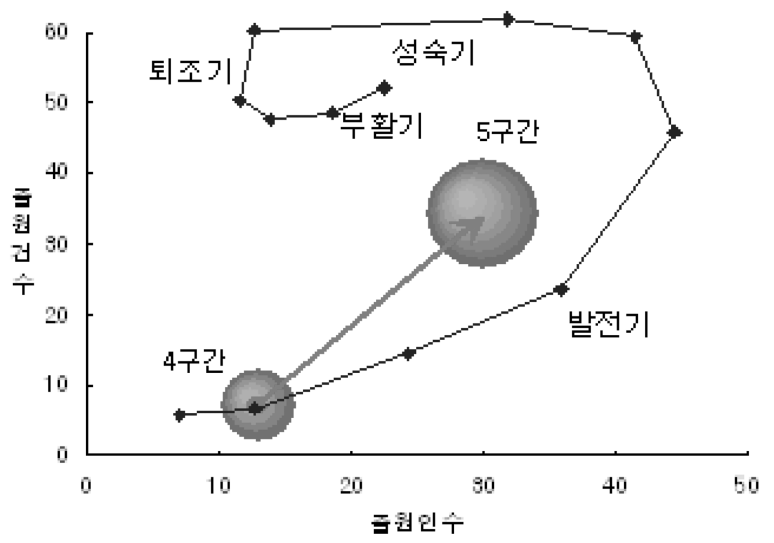

(1 구간( 88), 2 구간(89 92), 3 구간(93 96), 4 구간(97 00), 5 구간 (01 04))

Fig. 5. 한국특허의 구간별 특허 포트폴리오 (출원년도 기준: 2004년)

기술추이 포트폴리오이다. 본 포트폴리오는 크게 4단계로 구 분되며, 각각의 사항은 다음과 같다. (1) 발전기: 출원인 수와 특허출원건수가 모두 증가하는 단계로서, 이는 시장선점을 위 해 기술개발에 참여하는 기업수가 점차 증가하며 각 기업의 기술개발활동이 활발하게 이루어지는 것을 의미 한다. (2) 성 숙기: 기술개발이 포화된 상태로서 이는 시장에 참여하는 기 업이 포화상태에 이르며 기술개발활동은 점차 감소하는 현상 을 의미한다. (3) 퇴조기: 사양기술로써 기술개발에 참여하는 기업수와 기술개발활동이 점차 감소하는 것을 의미한다. (4) 회복기: 새로운 기술의 등장으로 기술개발이 다시 활발해지면 서 특허출원수가 증가하는 것을 의미한다 [12-21].

Fig. 5는 한국특허의 구간별 특허 포트폴리오를 나타낸 것 으로, 결론적으로 한국은 지금 발전기에 있음을 확인 할 수 있 었다. 4 구간에 개인 등에 의해 수소저장용 탄소재료에 대한 적
은 수의 출원이 있었으나, 5구간부터 한국기업으로서 (주)넥센 나노텍과 한국공공기관으로서 한국화학연구원과 한국과학기 술원의 활발한 연구활동과 특허활동 및 소니로서 대표되는 외 국기업들의 한국으로의 진출에 의한 영향인 것으로 판단된다.

Fig. 6는 미국의 구간별 특허 포트폴리오를 나타낸 것으로 미국 또한 현재 발전기상에 위치한 것이 확인되었다. 1구간부 터 4 구간까지는 소수의 등록권자에 의한 소수의 등록건이 이 루어지다가 5구간에 들어서 다수 등록권자의 소수 등록과 더 불어, 특히 Sony Corporation사의 미국으로의 진입과 Energy Conversion Devices Inc 및 Proton Energy Systems, Inc 등의 기 업들의 왕성한 특허활동에 힘입은 것으로 판단된다.

일본특허의 구간별 특허 포트폴리오를 살펴보면 (Fig. 7), 한 국, 미국과 동일하게 발전기 상에 위치한 것을 확인할 수 있 다. 4구간과 5구간에 걸쳐, 세계적 전자업계인 Sony Cooperation과 자동차 업계인 Toyota Motor Corp. 및 Nissan Motor Co. Ltd.의 두드러진 연구활동과 특허활동의 영향인 것으로 분석 된다.

Fig. 8은 유럽특허의 구간별 특허 포트폴리오로서 한국, 미국, 일본과 동일하게 발전기 상에 위치하고 있다. 하지만 미국, 일 본의 경우 기업중심으로 특정 대기업에서 정력적인 특허활동 이 관찰된 반면 유럽특허에서는 특정 출원인에 의한 집중적인 특허활동에 의한 것이 아니라, 수소저장용 매체로서 탄소재료 에 대한 점진적인 출원인들의 관심에 의한 것으로 판단된다.

상기의 포트폴리오 관찰을 통해, 탄소재료를 이용한 수소저 장에 관한 특허는 한국, 미국, 일본, 유럽에서 동일하게 발전 기 상에 위치하고 있는 것으로 확인되었다. 앞서 언급하였듯 이 발전기란 특허건수와 출원인 수가 동일하게 모두 증가되는 시기로 해당 분야에 대한 높은 관심과 더불어 많은 연구결과 가 나타나는 시기라 할 수 있다. 이는 탄소재료를 이용한 수 소저장에 관해 전세계적으로 먼저 기술적으로 선점하기 위한

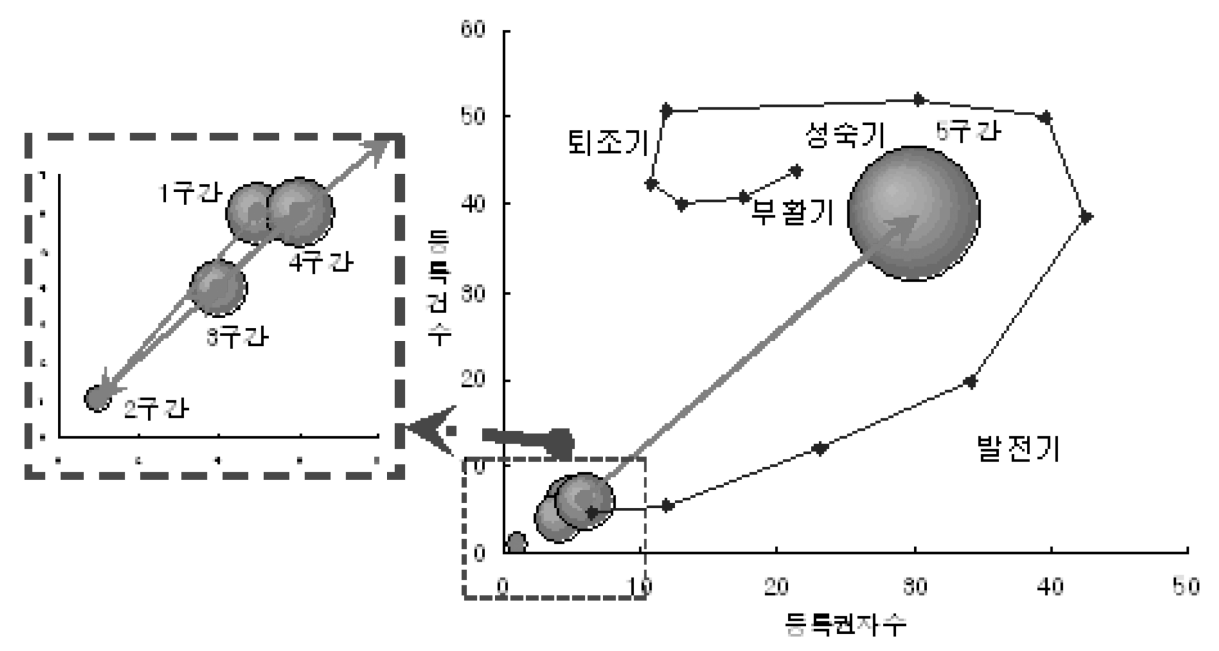

(1 구간( 90), 2 구간(91 94), 3 구간(95 98), 4 구간(99 02), 5 구간 (03 06))

Fig. 6. 미국특허의 구간별 특허 포트폴리오 (등록년도 기준: 2006년) 


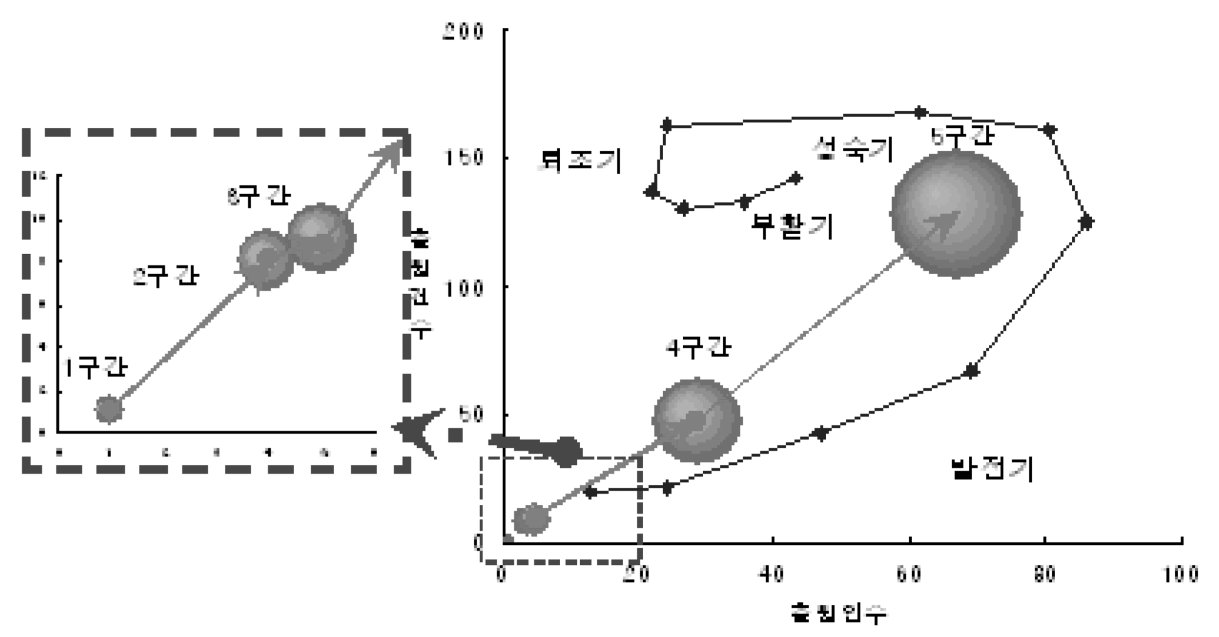

(1 구간( 88), 2 구간(89 92), 3 구간(93 96), 4 구간(97 00), 5 구간 (01 04))

Fig. 7. 일본특허의 구간별 특허 포트폴리오 (출원년도 기준: 2004년)

치열한 연구 전쟁이 일어나고 있음을 반증하는 증거라 할 수 있다. 특히 일본 및 미국의 경우 몇 개 초대기업을 중심으로 특허활동이 주로 이루어 지고 있어, 기술적 우위를 선점한 기 업이 해당 분야의 원천기술 및 베타적 기술영역을 넓혀가고 있음이 확인되었다. 반면 우리나라의 경우 동일 하게 발전기 에 속하긴 하지만 일본 및 미국에 비해 낮은 출원건수와 출원 인을 가지고 있으며, 타국과의 근본적인 차이점은 특허활동을 선도하는 주체, 즉 기업의 부재이다.

현재 일본의 경우 Toyota 및 Nissan을 중심으로 수소자동차 개발을 위해 왕성한 특허활동이 이루어지고 있으며, 이에 관 련된 에너지 관련업체의 특허활동 또한 무시할 수 없는 실정 이다. 더불어 세계적 전자회사인 Sony의 세계적 특허출원 움 직임도 무시할 수 없을 정도임을 이미 제시한 바 있다. 이는 수소자동차의 실용화 및 보급이 멀지 않았기 때문이며, 향 후

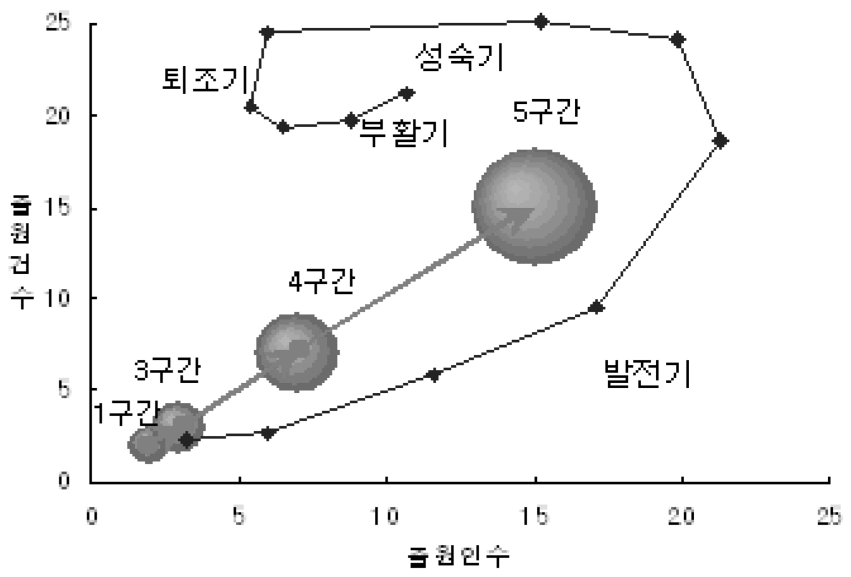

Fig. 8. 유럽특허의 구간별 특허 포트폴리오 (출원년도 기준: 2004년)
수소자동차의 보급에 따른 막대한 경제적 손익적 차원에서 볼 때 국내 기업들의 정력적인 특허활동이 요구되는 상황이라고 할 수 있다.

\section{3. 결 론}

본 특허동향 총설에서는 전편에서 각국의 특허건수 및 소재 별 특허동향에 이어 소재별 연구주체 및 특허 포트폴리오에 대하여 관찰하여 보았다.

특허 선도국인 일본 및 미국의 경우 자동차 관련 초대기업 을 중심으로 탄소재료 전분야에 걸친 특허활동이 두드러지고 있으며, 유관 기업인 에너지 및 전자 관련 업체의 특허활동도 활발하여, 특허권 선점 및 배타적 영역 확대에 열을 올리고 있 는 실정이다. 더불어 최근 들어 이러한 특허활동은 속도가 붙 고 있으며, 수소자동차의 상용화를 앞둔 시점에서 이들 기업 의 특허로 인한 경제적 파급효과는 막대할 것으로 판단된다.

한국의 경우 수소저장 분야에서 후발주자로 동참한 시기가 짧기 때문에 아직까지 일본, 미국과 그 수준을 비교하기에는 미미한 수준이다. 하지만 한국특허는 타 기술 선진국과는 다 르게 특허활동을 주도하는 대기업 및 자동차 관련 회사의 부 재가 눈에 띤다. 한국은 현대, 삼성, 기아, 대우 등 많은 자동 차 관련 대기업을 보유하고 있는 나라로서 그 어느 나라보다 도 수소자동차의 상용화 및 보급에 많은 관심을 가지고 있는 나라이다. 또한 자국 내에 가솔린의 생산이 없기 때문에 수소 자동차의 보급은 이러한 문제를 해결할 수 있는 키워드로서 작동될 수 도 있는 사항이다. 따라서 일본과 같이 국내의 메 이져급 대기업들의 정력적 특허활동이 반드시 필요하며, 이에 대한 정부의 지원도 충분히 이루어져야 할 것으로 판단된다. 
이를 통해 향후 수소자동차 시대에 일본, 미국과 어깨를 견주 는 수소 과학 강국으로 자리매김해야 할 것으로 판단된다.

\section{감사의}

본 자료는 교육인적자원부의 Connect Korea 사업의 지원을 받아 인하대학교 선도 TLO사업의 일환으로 한국특허정보원 에 의뢰하여 작성한 특허맵에서 인용하였습니다.

이 연구(논문)은 과학기술부의 지원으로 수행하는 21 세기 프 론티어연구개발사업(수소에너지사업단)의 일환으로 수행되었 습니다.

\section{References}

[1] Li, Y.; Yang, R. T. J. Am. Chem. Soc. 2006, 128, 8136.

[2] Lueking, A. D.; Yang, R. T. Appl. Catal. A 2004, 265, 259.

[3] Kim, B. J.; Park, S. J. Nanotechnology 2006, 17, 4395.

[4] Kim, B. J.; Park, S. J. J. Colloid Interface Sci. 2007, 311, 619.

[5] Kim, B. K.; Ryu, S. K.; Kim, B. J.; Park, S. J. J. Ind. Eng. Chem. 2006, 12, 121.

[6] Dillon, A. C.; Jones, K. M.; Bwkkedahl, T. A.; Kiang, C. H.; Bethune, D. S.; Heben, M. J. Nature 1997, 386, 377.

[7] Yim, Y. E.; Mays, T.; McEnamey, B.; Langmuir 2000, 103, 10521.

[8] Yang, R. T. Carbon 2000, 38, 623.
[9] Lueking, A. D.; Pan, L.; Narayanan, D. L.; Clifford, C. E. B. J. Phys. Chem. B 2005, 109, 12710.

[10] Yoo, E.; Gao, L.; Komatsu, T.; Yagai, N.; Arai, K.; Yamazaki, T.; Matsuishi, K.; Matsumoto, T.; Nakamura, J. J. Phys. Chem. B 2004, 108, 18903.

[11] Bansal, R. C.; Goyal, M. Activated Carbon Adsorption, CRC Press, Boca Raton, 2005.

[12] Nippon Telegr \& Teleph Corp., Carbon materials for storing hydrogen, JP-2003-171111.

[13] Toyota Central Res \& Dev Lab Inc., Porous activated carbon for hydrogen storage and manufacturing method thereof, JP-2003-277037

[14] Yazaki Corp., Graphite Intercalating compound, JP-1989204013.

[15] Alsin Seiki Co. Ltd, Hydrogen storage materials and its manufacturing method, JP-2003-311149.

[16] Hitachi Powdered Metals Co. Ltd, Nissan Motor Co. Ltd, Graphite-based hydrogen-occluding material and method for producing the same, JP-2003-321216.

[17] Asahi Kasei Corp., New carbon grain of nanosized, and production method thereof, JP-2004-182509

[18] Araco Corp., Carbon structure, JP-2004-002053.

[19] Enernext, LLC, Method for sorption and desorption of molecular gas contained by storage sites of nano-filament laded reticulated aerogel, US-6,906,003.

[20] Futaba Corp., Method for producing hydrogen occlusion material, US-6,602,485.

[21] Carnegie Mellon Univ., Process for the preparation of nanostructured materials, US-7,056,455. 